\title{
Corporate sustainability effectiveness: social and environmental reports grade of disclosure and economic performance
}

Donato Calace, Ph.D. Student

LUM Jean Monnet University 


\section{INDEX}

1. BACKGROUND THEORY;

2. METHODOLOGY

3. RESULTS

4. DISCUSSION AND

CONCLUSION 


\section{INDEX}

\section{BACKGROUND THEORY}




\section{"there's no alternative to sustainable development»}

(Nidumolu, Prahalad, \& Rangaswami, p.57, 2009)

Nowadays, the leading paradigm for future development is the sustainable one. There is a growing consensus from institutions, regulators, stakeholders, managers and researchers that believe in the "sustainability imperative" (Lubin \& Esty, 2010) 


\section{A business case for sustainability}

Most of research has proved a business case for sustainability, showing that social and environmental friendly policies and strategies pay in terms of superior financial, operative and competitive performance
Sustainability has found its conversion into the firm dimension. Concepts and theories such as corporate social responsibility (CSR), corporate sustainability, triple bottom line and sustainable entrepreneurship were born in order to describe whether and how sustainability exist at the firm level (Dyllick \& Hockerts, 2002; Elkington, 1997; Van Marrewijk, 2003; Young \& Tilley, 2006; Schaltegger \& Wagner, 2011) 

At the business level, the "mantra" of sustainability is "often equated with eco- efficiency", disregarding the effectiveness of sustainable strategies and policies
(Dyllick \& Hockerts, 2002)

There is a growing interest the issue is not anymore in finding in which terms whether being "green" or and with which effects not, , but how being "green", sustainability paradigm i.e. in which ways and can exist at business level, following which principles i.e. "to bring sustainability sustainable strategies are down to earth" (Reinhardt, 1999; implemented and carried Dyllick, 1999; Fussler \& James, 1996).

OUt (Roca \& Searcy, 201 1; Smith, 2003) 
"in general corporate sustainability and CSR refer to company activities - voluntary by definition demonstrating the inclusion of social and environmental concerns in business operations and in interactions with stakeholders"

\section{Corporate Sustainabilty theory}

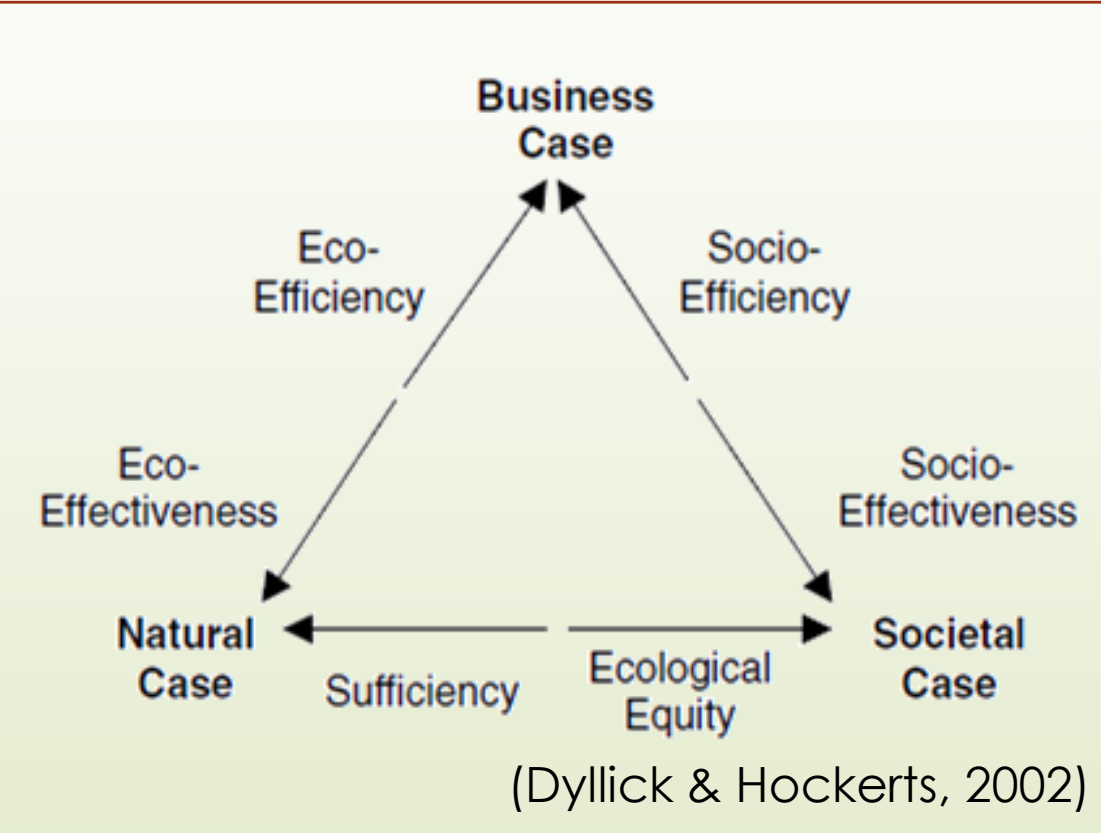

Corporate sustainability theory aims to move beyond the efficiency point of view, building an inclusive and effective framework of social, environmental and economic value
While efficiency deals with doing things right, effectiveness regards doing right things, that is meeting the objective being an ecologically sustainable company by answering the question: how close is the firm to the environment's carrying capacity?. Efficiency "is not a strategy over the long term, because it does not reach deep enough" (McDonough \& Braungart, p. 85, 1998) 


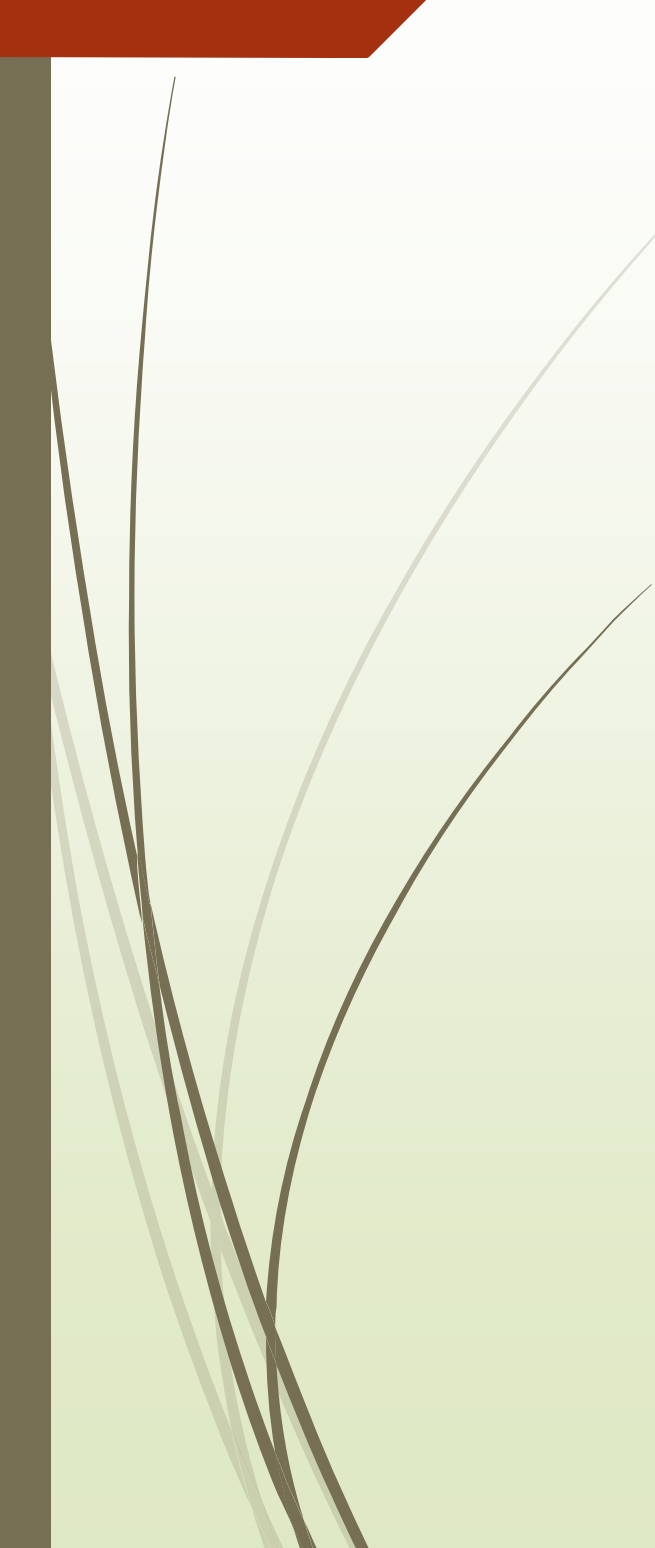

The aim of this study is not to demonstrate whether being green pays or not

The analysis moves beyond the traditional question "does it pay to be green?", exploring how different sustainable stances determine financial performance. 


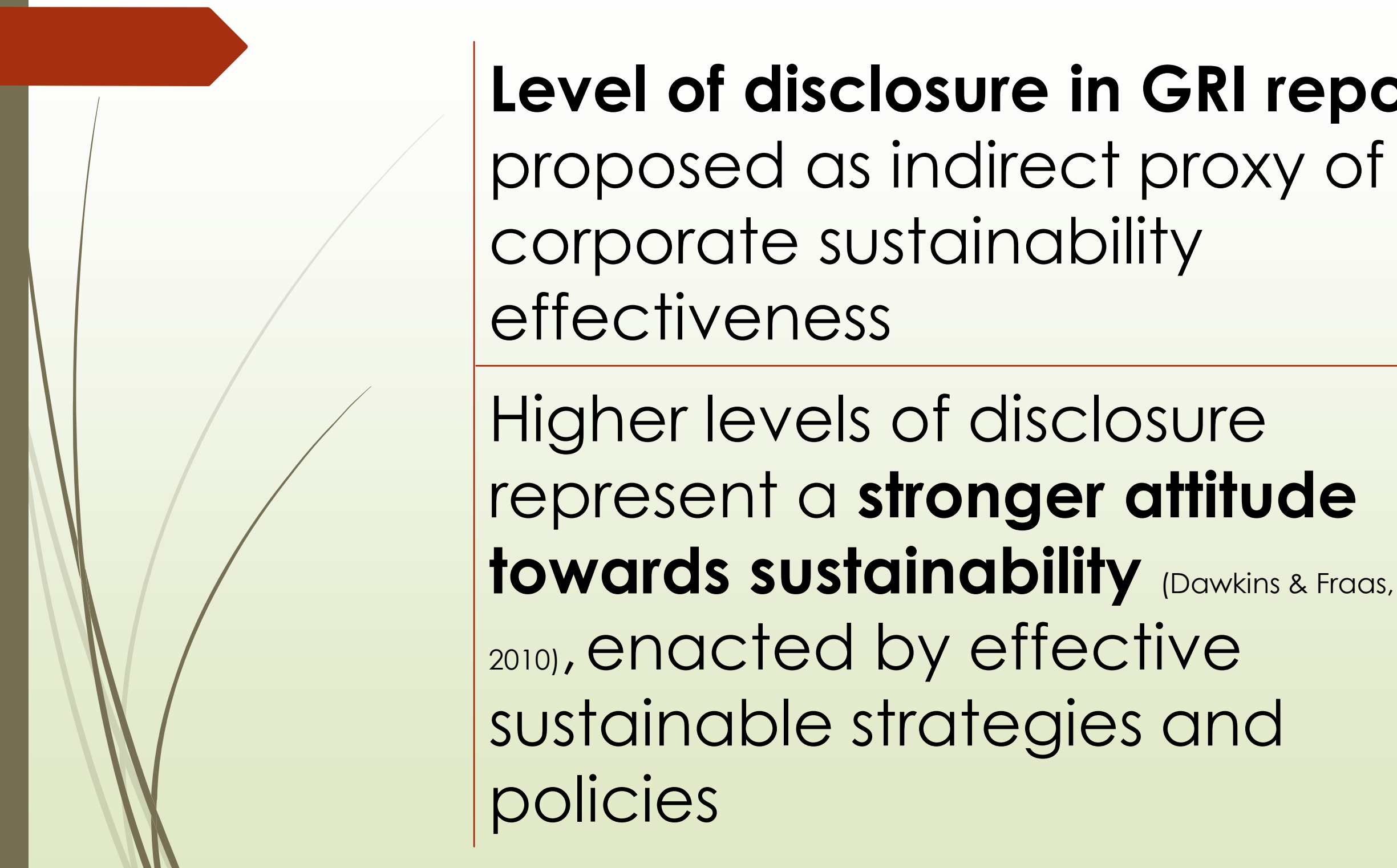




\section{BACKGROUND THEORY}

Level of disclosure and environmental performance

- Empirical evidence regarding level of disclosure and

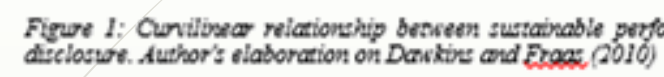

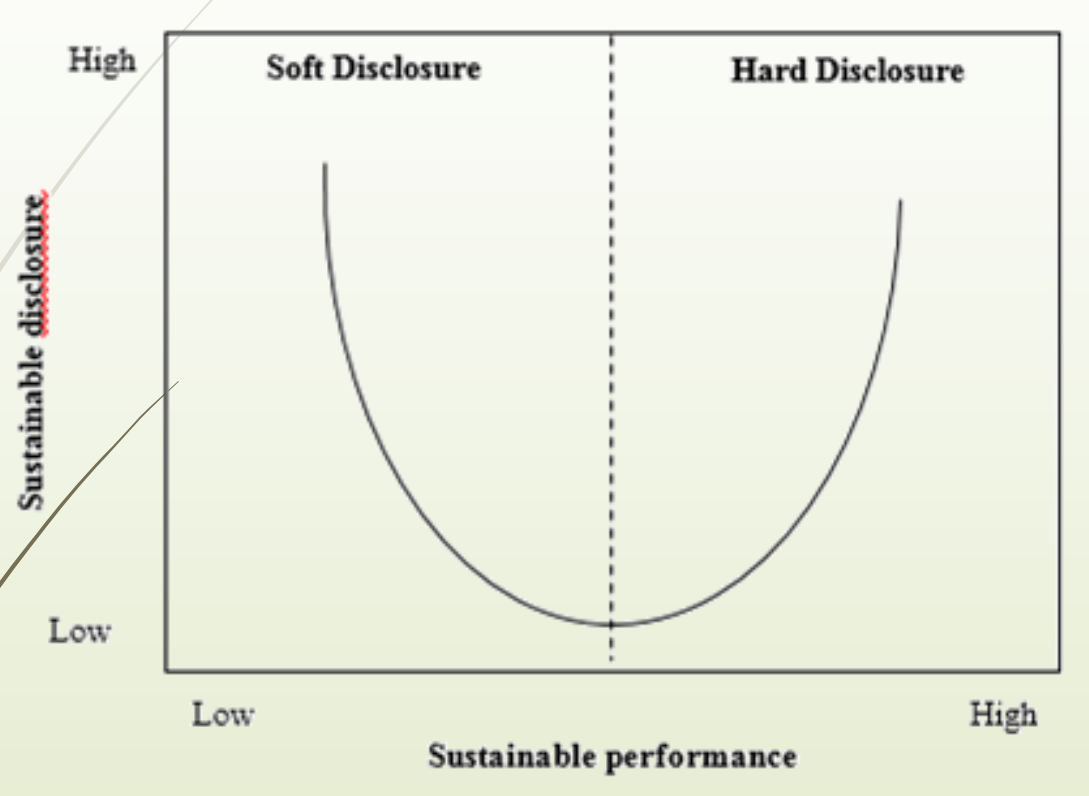
environmental performance is mixed;

- there are several both internal and external factors, further than the sustainable performance, inducing firms' disclosure: stakeholders' pressures, mandatory requirements, industrial peers' strategies, image and reputation, media coverage;

- There are two opposite stances: voluntary disclosure theory (positive relationship) and socio-political theories (negative relationship);

- Recent studies are trying to overcome this dichotomy in theory, looking for an integrative interpretation of the two stances. The quality of disclosure is the key in this process. "Companies with

- Hard disclosure: measurable, verifiable, non imitable, used to underline superior performance;

- Soft disclosure: unmeasurable, unverifiable, used to defend legitimacy superior environmental performance [...] seek to reveal their performance type, something not directly observable to investors and other stakeholders, through direct voluntary disclosures that cannot be easily mimicked by poor performers" (Clarkson, Li, Richardson, \& Vasvari, p.6, 2007). 


\section{Economic performance}

Academic positions regarding the effects of firms' sustainable strategies and policies on economic performances are various.

On one side, there are scholars who believe that a sustainability-driven attitude leads firms to increasing efficiency, strengthening brand and market value, and improving competitiveness (Hart \& Ahuja, 1996; Porter \& Van der Linde, 1995; Porter \& Kramer, 2011).

On the other side, there are opposing views according to which the only responsibility of a company is the use of its resources to engage in activities designed to increase profits (Friedman, 1970; Bragdon \& Marlin, 1972; Vance, 1975; Brammer, Brooks, \& Pavelin, 2006)

Concerning economic measures, researchers distinguish between financial performance and operating results. This study uses market capitalization as measure of economic performance.

Empirical results show that sustainable performance has higher significance in terms of financial measures, insofar as these last better stand for long-term outcomes: improvements in the short-term are marginal or not significant at all (Pogutz \& Russo, 2009; Connelly \& Limpaphayom, 2004; Lee, Faff, \& Langfield-Smith, 2009) 


\section{Hypotheses development}

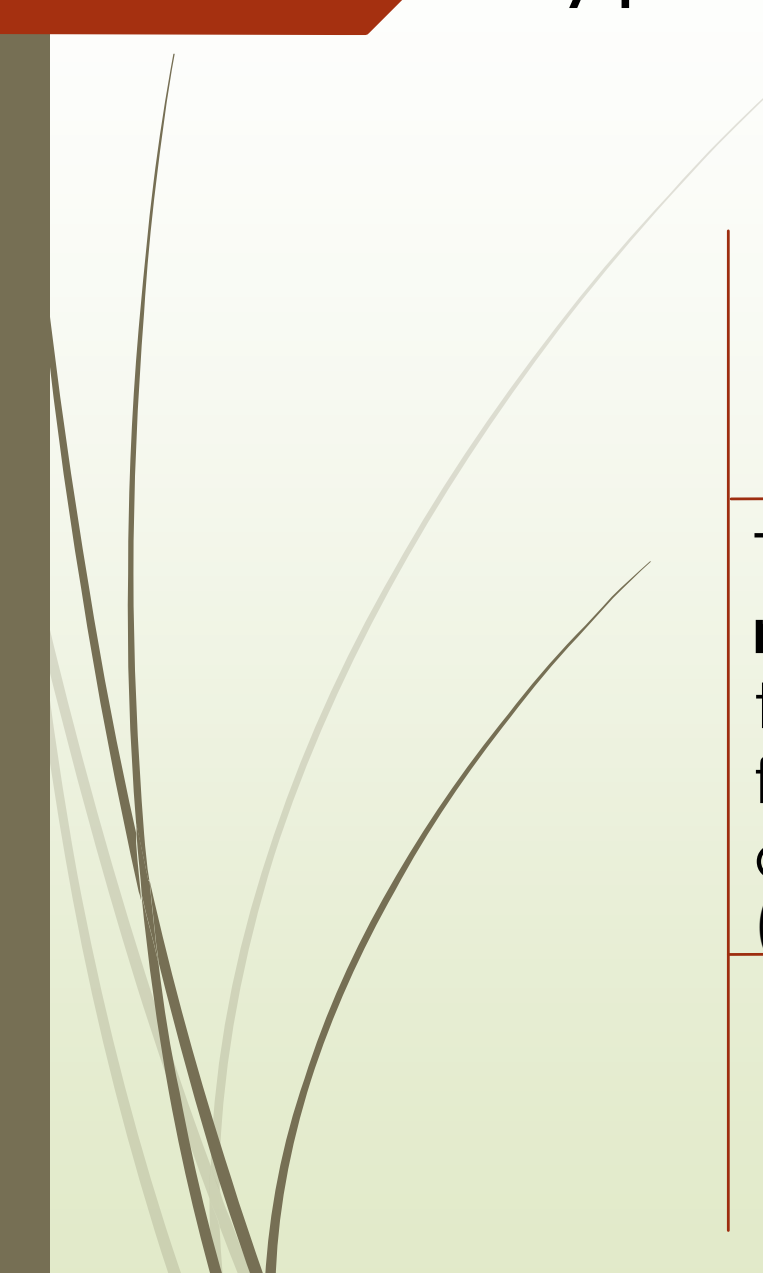

Hypothesis 1: The issuance of a GRI referenced sustainability report has a positive impact on firms' market value

The publication of a report, even if guided by GRI guidelines, does not represent the maximum level of disclosure. "it may be that companies that have a adopted a full disclosure have done so because they fundamentally believe that their strengths outweigh their weaknesses and are committed to environmental disclosure as a matter of value". (Dawkins and Fraas, 2010, p.385-386)

Hypothesis 2: the issuance of a full-disclosed GRI report has a higher positive impact on firms' market value than the single publication of a GRI report 


\section{INDEX}

2. METHODOLOGY 


\section{METHODOLOGY}

\section{The sample}

The final sample includes companies operating in $\mathbf{7}$ industries (agriculture, chemicals/heavy industry, light industry, services/IT, energy, shipping/transport/distribution and wholesale/retail/food), coming from 26 different countries representing 6 world areas (North America, South America, Europe, Asia, Far East, Oceania).

\begin{tabular}{|l|l|l|l|l|l|l|l|}
\hline industry & No. of firms & $\begin{array}{l}\text { Avg. profits } \\
\text { (B. \$) }\end{array}$ & $\begin{array}{l}\text { Std. Dev. } \\
\text { Profits (B. \$) }\end{array}$ & $\begin{array}{l}\text { Avg. } \\
\text { Assets (B. \$) }\end{array}$ & $\begin{array}{l}\text { Std. Dev. } \\
\text { Assets (B. \$) }\end{array}$ & $\begin{array}{l}\text { Avg. } \\
\text { net revenues } \\
\text { (B. \$) }\end{array}$ & $\begin{array}{l}\text { Dev. Std. net } \\
\text { revenues (B. \$) }\end{array}$ \\
\hline agriculture & 4 & 2,71 & 1,70 & 38,81 & 10,67 & 49,30 & 31,74 \\
\hline $\begin{array}{l}\text { chemicals/ } \\
\text { heavy industry }\end{array}$ & 24 & 7,36 & 6,06 & 87,02 & 37,94 & 64,18 & 50,03 \\
\hline energy & 29 & 10,36 & 12,53 & 125,44 & 109,45 & 117,92 & 122,14 \\
\hline light industry & 55 & 3,46 & 5,28 & 85,00 & 118,94 & 63,06 & 55,57 \\
\hline services/IT & 23 & 5,85 & 5,20 & 103,37 & 78,34 & 66,70 & 33,65 \\
\hline $\begin{array}{l}\text { shipping/ } \\
\text { transport/ } \\
\text { distribution }\end{array}$ & 16 & 2,12 & 2,18 & 62,18 & 70,04 & 62,70 & 31,88 \\
\hline $\begin{array}{l}\text { Wholesale/ } \\
\text { retail/food }\end{array}$ & 28 & 3,61 & 4,11 & 52,12 & 45,43 & 72,31 & 82,71 \\
\hline
\end{tabular}




\section{METHODOLOGY}

\section{Why GRI level of disclosure?}

This measure has three main advantages.

- First, it is endowed with hard disclosure, which is verifiable, measurable and not imitable by poor sustainable performers. Therefore, it overwhelms the debate between the voluntary disclosure theory and the sociopolitical one, suggesting a combination of the two.

Second, GRI Guidelines are the most recognized framework for sustainability reporting and exhibits several features of an established institution, such as broad uptake and legitimacy.

- Third, GRI reporting framework includes environmental, societal and economic disclosures, applying a triple bottom line approach.

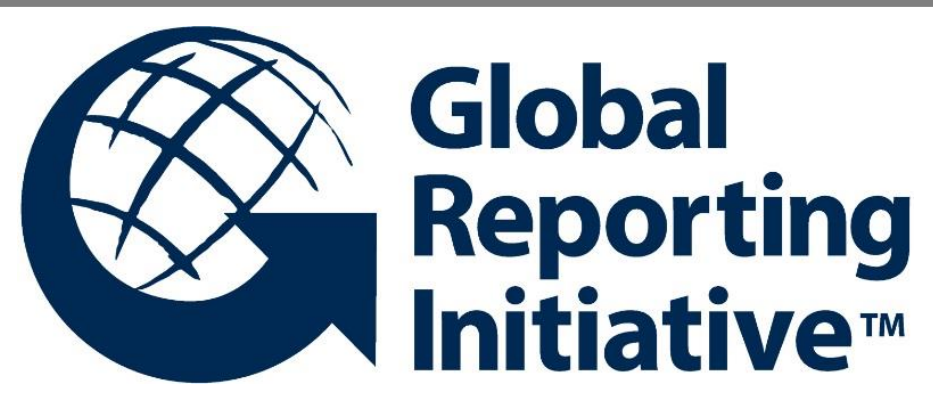

The Global Reporting Initiative is a non-profit organization founded in 1997 in Boston. Initially, it was a department of the Coalition for Environmentally Responsible Economies (CERES) with the mandate to develop an inclusive, multi-stakeholder reporting framework. . Today, the Sustainability Disclosure Database features more than 13000 reports from over 5000 organizations. 


\section{METHODOLOGY}

\section{GRI Application Level}

The "Applications Levels" ( $A L)$ system assesses the grade of disclosure, giving a score that goes from $\mathbf{C}$ (minimum disclosure) to $\mathbf{A}$ (full disclosure). Report makers self-declare their Application Level, and, in addition, they can have their selfdeclaration externally assured by a third party (receiving a "+" to their AL) and/or request the GRI to check the self-declaration.

\begin{tabular}{|c|c|c|c|}
\hline Profile Disclosure & $\begin{array}{l}\text { Report on: } \\
1.1 \\
2.1-2.10 \\
3.1-3.8,3.10-3.12 \\
4.1-4.4,4.14-4.15\end{array}$ & $\begin{array}{l}\text { Report on all criteria } \\
\text { listed for level C, plus: } \\
1.2 \\
3.9-3.13 \\
4.5-4.13,4.16-4.17\end{array}$ & $\begin{array}{l}\text { Same as requirement } \\
\text { for Level B }\end{array}$ \\
\hline $\begin{array}{l}\text { Disclosure on } \\
\text { Management } \\
\text { Approach }\end{array}$ & Not required & $\begin{array}{l}\text { Management } \\
\text { approach disclosure for } \\
\text { each indicator } \\
\text { category }\end{array}$ & $\begin{array}{l}\text { Management } \\
\text { approach disclosure for } \\
\text { each indicator } \\
\text { category }\end{array}$ \\
\hline $\begin{array}{l}\text { Performance } \\
\text { Indicators \& } \\
\text { Sector } \\
\text { Supplements } \\
\text { Performance } \\
\text { Indicators }\end{array}$ & $\begin{array}{l}\text { Report fully on a } \\
\text { minimum of any } 10 \\
\text { performance indicators, } \\
\text { including at least one } \\
\text { from each of: social, } \\
\text { economic, and } \\
\text { environment. }\end{array}$ & $\begin{array}{l}\text { Report fully on a } \\
\text { minimum of any } 20 \\
\text { performance indicators, } \\
\text { including at least one } \\
\text { from each of: } \\
\text { economic, } \\
\text { environment, human } \\
\text { rights, labor, society, } \\
\text { product responsibility }\end{array}$ & $\begin{array}{l}\text { Respond on each core } \\
\text { and Sector Supplement } \\
\text { indicator with due } \\
\text { regard to the materiality } \\
\text { principle by either: A) } \\
\text { reporting on the } \\
\text { indicator or B) } \\
\text { explaining the reason } \\
\text { for its omission }\end{array}$ \\
\hline $\begin{array}{l}\text { Report } \\
\text { Application Level }\end{array}$ & C & $t_{1}$ & 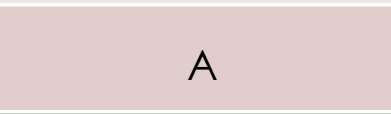 \\
\hline
\end{tabular}

SAMPLE DATA

\begin{tabular}{|l|l|l|}
\hline $\begin{array}{l}\text { GRI } \\
\text { Application } \\
\text { Level }\end{array}$ & No. of firms & $\begin{array}{l}\text { Third party } \\
\text { checked - GRI } \\
\text { checked }\end{array}$ \\
\hline A & 5 & Yes \\
\hline A+ & 75 & Yes \\
\hline B & 9 & Yes \\
\hline B+ & 26 & Yes \\
\hline C & 2 & Yes \\
\hline C+ & 3 & Yes \\
\hline Undeclared & 1 & Yes \\
\hline
\end{tabular}




\section{METHODOLOGY}

\section{Econometric model}

Ohlson, (1995) provides a model for examining the variation of market value, or price, of the firm at date $t$ when a vector of other value-relevant information changes. Burnett, Skousen, \& Wright (2011) use such model in their analysis of ecoeffective management, linking firm value and corporate sustainability.

GRI Application Level is an ordinal, non-metric, scale. Its values are rankordered, but are not equidistant one from the other. For this reason, statistical techniques such as correlation, regression, and analysis of variance are not suitable. I

\begin{tabular}{|l|l|l|}
\hline GRI1 & No issuance of a GRI report & $\begin{array}{l}\text { Issuance of a GRI report in at } \\
\text { least one of the three years } \\
\text { of analysis }\end{array}$ \\
\hline GRI2 & $\begin{array}{l}\text { Publication of a GRI report } \\
\text { with an application level } \\
\text { score lower than A in each of } \\
\text { the three years of analysis }\end{array}$ & $\begin{array}{l}\text { Publication of a GRI report } \\
\text { with an A application level } \\
\text { score in at least one of the } \\
\text { three years of analysis }\end{array}$ \\
\hline VALUE & 0 & \\
\hline
\end{tabular}
converted the level of disclosure into two dichotomous variables, GRII and GRI2. 


\section{Econometric model}

$$
M K V_{i t}=a_{0}+a_{1} T S E_{i t}+a_{2} R O A_{i t}+a_{3} C F O_{i t}+a_{4} L E V_{i t}+a_{5} G R I 1_{i t}+a_{6} G R I 2_{i t}+e_{i t}
$$

$$
\begin{array}{r}
M K V_{i t}=\text { market capitalization of firm i at date } \dagger \\
T S E_{i t}=\text { total shareholder equity } \\
R O A_{i t}=\text { return on activities } \\
C F O_{i t}=\text { cash flow from operations } \\
L E V_{i t}=\text { long-term debt/equity }
\end{array}
$$

With the aim of mitigating heteroscedasticity and controlling for size, net revenues scale MKV, TSE and CFO. Moreover, industry, year and geographical dummies are included in the analysis to control their effects. To test the validity of the model beyond endogeneity issues, I run a second version of the model with MKV values of the subsequent years $\left(\mathbf{M K V}_{\mathbf{i t}+\mathbf{1}}\right)$ as dependent variable. In this case, I drop observations from the last year of analysis, studying a two-year (2010-2011) panel. 


\section{INDEX}

\section{RESULTS}


Weighted Least Squares (WLS) following Mundlak (1978) technique and Model 1 using 536 observations. Included 179 cross-sectional units per 3 years. Dependent variable: market capitalization. Weights based on per-units error variances.

\begin{tabular}{|l|c|c|c|c|c|}
\hline & Coefficient & Std. Error & t-ratio & p-value & \\
\hline const & -0.0138859 & 0.164685 & -0.0843 & 0.93284 & \\
\hline Equity & 1.02961 & 0.255027 & 4.0373 & 0.00006 & $* * *$ \\
\hline Cash flow & 0.910707 & 0.285011 & 3.1953 & 0.00148 & $* * *$ \\
\hline ROA & -0.152596 & 0.297717 & -0.5126 & 0.60848 & \\
\hline Leverage & 0.00897531 & 0.0111752 & 0.8031 & 0.42226 & \\
\hline GRI1 & 0.292201 & 0.0349656 & 8.3568 & $<0.00001$ & $* * *$ \\
\hline GRI2 & -0.416158 & 0.0383412 & -10.8541 & $<0.00001$ & $* * *$ \\
\hline Mean equity & -0.486558 & 0.261224 & -1.8626 & 0.06309 & $*$ \\
\hline Mean cash flow & 4.8357 & 0.398384 & 12.1383 & $<0.00001$ & $* * *$ \\
\hline Mean leverage & -0.0486779 & 0.0122448 & -3.9754 & 0.00008 & $* * *$ \\
\hline Mean ROA & 1.95122 & 0.365727 & 5.3352 & $<0.00001$ & $* * *$ \\
\hline Industry control & & & Yes & & \\
\hline Geo control & & & Yes & & \\
\hline Year control & & & Yes & & \\
\hline
\end{tabular}

${ }^{* * *}$ indicate significance at $p \leq 0,01$

** indicate significance at $p \leq 0,05$

* indicate significance at $p \leq 0,1$

R-squared $(0,88)$ and adjusted R-squared $(0,87)$ show that more than two-thirds of the variance of the dependent variable are explained by the model.

The variables of interest, GRI1 and GRI2 are both significant at 0,01 level. GRI1 effect is positive, confirming hypothesis 1. Therefore, the issuance of a GRI report determines a significant positive effect on market capitalization. Surprisingly, GRI2 has a negative coefficient, rejecting the proposition of hypothesis 2. A full disclosure stance is not valued by the market, at least in the period of observation. 
Weighted Least Squares (WLS) following Mundlak (1978) technique and Model 2 using 358 observations. Included 179 cross-sectional units per 2 years. Dependent variable: market capitalization $t+1$. Weights based on perunits error variances.

\begin{tabular}{|l|c|c|c|c|c||}
\hline & Coefficient & Std. Error & t-ratio & p-value & \\
\hline const & -0.254073 & 0.174866 & -1.4530 & 0.14717 & \\
\hline Equity & -0.201208 & 0.344413 & -0.5842 & 0.55947 & \\
\hline Cash Flow & -0.317027 & 0.514773 & -0.6159 & 0.53841 & \\
\hline ROA & -0.715084 & 0.275153 & -2.5989 & 0.00977 & $* * *$ \\
\hline Leverage & 0.0210082 & 0.0332721 & 0.6314 & 0.52820 & \\
\hline GRI1 & 0.327056 & 0.0305042 & 10.7217 & $<0.00001$ & $* * *$ \\
\hline GRI2 & -0.503471 & 0.0354909 & -14.1859 & $<0.00001$ & $* * *$ \\
\hline Mean equity & 0.663248 & 0.355385 & 1.8663 & 0.06288 & $*$ \\
\hline Mean cash flow & 6.05749 & 0.650826 & 9.3074 & $<0.00001$ & $* * *$ \\
\hline Mean leverage & -0.0530417 & 0.0262284 & -2.0223 & 0.04394 & $* *$ \\
\hline Mean ROA & 2.45574 & 0.240566 & 10.2082 & $<0.00001$ & $* * *$ \\
\hline Industry control & & & Yes & & \\
\hline Geo control & & & Yes & & \\
\hline Year control & & & Yes & & \\
\hline
\end{tabular}

*** indicate significance at $p \leq 0,01$

** indicate significance at $p \leq 0,05$

* indicate significance at $p \leq 0,1$

R-squared $(0,94)$ and adjusted R-squared $(0,93)$ confirm that the model explains most of the variation of the dependent variable.

This robustness check shows that the predictors' effects are still significant at 0,01 level. In particular, the signs of the variables of interest are confirmed. Thus, as before, data supports hypothesis 1 and rejects hypothesis 2. GRII has a positive coefficient, even greater than the one depicted in Model 1, while GRI2 has again a negative effect on market capitalization, with a higher coefficient than the one presented in Model 1. This may suggest that GRI2 sign could change if observed in a longer period. 
Model 3: looking for long period advantages

Literature indicates that the outcomes of sustainable stances become manifest in the long period. As collected data covers only a 3-years period, it is not sufficient to draw conclusion regarding the long run.

Here, I propose to juxtapose the interaction between GRII and Leverage against GRI2 and Leverage. Indeed, high levels of financial leverage have a negative effect on market value. Evidence from research indicates that good environmental performers take advantage of a lower cost of capital because moneylenders consider them less risky. 


\section{INDEX}

\section{DISCUSSION AND CONCLUSION}




\section{This paper contributes to corporate sustainability theory in two ways.}

Firstly, it provides an innovative indirect measure for corporate sustainability effectiveness, which is level of disclosure in GRI reports.

Secondly, it considers different approaches towards sustainability and analyzes their effects in term of economic performances.

Findings suggest that sustainable operating firms have economic returns in the period of analysis, which is short. However, if one considers how much these firms are sustainable there are still improvement margins. Indeed, they are not reporting on all GRI framework items. Under this point of view, their sustainable strategies are less effective than those enacted by fully disclosing companies.

A full disclosure stance determines a negative and statistically significant effect on market value in the period of analysis. However, fully disclosing firms take advantage of a lower cost of debt capital, because moneylenders consider them less risky than firms with partial disclosure. In the long run, this could be a source of competitive advantage for fully disclosing firms against partially disclosing ones. 
- Size bias: the Fortune Global 500 are the biggest companies in the world, thus generalization of results is limited to this kind of businesses;

- lack of direct testing of the relationship between level of disclosure and sustainable performance;

- Further research could build a simultaneous equation model or a structural equation model in order to test sustainable performance, level of disclosure and economic performance at the same time;

- This study focus on GRI Application Level as a whole: additional research could analyze the disclosure of specific items of GRI non-financial reports;

- It would be of interest to understand the components and indicators of disclosure quality, as well as to juxtapose the effects on firm performance of hard disclosure against soft disclosure. 


\section{Thank you.}

Donato Calace, Ph.D. Student

LUM Jean Monnet University 